\title{
What's in Alaska?
}

\section{Raymond Carver}

Carl got off work at three. He left the station and drove to a shoe store near his apartment. He put his foot up on the stool and let the clerk unlace his boot.

"Something comfortable," Carl said. "For casual wear."

"I have something," the clerk said.

He brought out three pairs of shoes and Carl said he would take the third pair, soft, beige-colored shoes that made his feet feel light and springy. He paid the clerk and put the box with his boots under his arm. He looked down at his new shoes as he walked. Driving home, his feet moved lightly and freely from accelerator pedal to brake to clutch.

"You bought some new shoes," Mary said. "Let me see."

"Do you like them?" Carl said.

"I don't like the color, but I'll bet they're comfortable. You needed new shoes."

He looked at the shoes again. "I've got to take a bath," he said.

"We'll have an early dinner," she said. "Helen and Jack asked us over tonight. She got him a water pipe for his birthday and they're anxious to try it out. They're funny." She looked at him. "Is it all right with you?"

"What time?"

“Around seven. After they put the kids to bed. Carl, we don't have to go."

"It's all right. Sure," he said. said.

She looked at his shoes again and sucked her cheeks. "Take your bath," she

He ran the water and took off his shoes and clothes. He lay in the tub for a while and then used a brush to get at the lube grease under his nails. He dropped his hands and then raised them to his eyes.

She opened the bathroom door. "I brought you a beer," she said. Steam drifted around her and out into the living room.

"I'll be out in a minute," he said. He drank some of the beer and looked at her. 
She sat on the edge of the tub and put her hand on his thigh. "Home from the wars," she said.

"Home from the wars," he said. "Lousy wars."

She moved her hand through the wet hair on his thigh. Then she clapped her hands. "Hey, I have something to tell you! I had an interview today, and I think they're going to offer me a job in Fairbanks."

"Alaska?" he said.

She nodded. "What do you think of that?"

"I've always wanted to go to Alaska. Does it look pretty definite?"

She nodded again. "They liked me. They said I'd hear next week."

"That's great. Hand me a towel, will you, I'm getting out."

"I'll go and set the table," she said.

His fingertips and toes were pale and wrinkled. He dried slowly and put on clean underwear, socks, clothes, and the new shoes. He combed his hair and went out to the kitchen. He drank another beer while she put dinner on the table.

"We're supposed to bring some creme soda and something to munch on," she said. "We'll have to go by the store."

He went on eating.

"We don't have to go," she said.

"Creme soda and munchies. Okay."

When they had eaten he helped her clear the table. Then they drove to the market and bought creme soda and potato chips, Frito chips, and onionflavored snack crackers. At the last minute he added a handful of U-No bars to the order. "Hey, yeah," she said when she saw them.

They drove home again and parked and then walked the block to Helen and Jack's.

Helen opened the door. Jack was in the shower. He had just gotten in from work, and his boots and dirty clothes were in front of the bathroom door. The door to the children's room was closed.

Carl put the sack on the dining room table. Mary sat down in the rocking chair and sniffed. "We're late," she said. "They started without us, Carl."

Helen laughed. "We had one when Jack came in. We haven't lighted the water pipe yet. We were waiting until you got here." She stood in the middle of the room, looking at them and grinning. "Let's see what's in the sack. Oh, wow! Say, I think I'll have one of these Frito chips right now. You guys want some?"

"We just ate dinner," Carl said. "We'll have some pretty soon." The water had stopped running and he could hear Jack whistling in the bathroom.

"We have some popsicles and some $M$ and M's," Helen said. She stood beside the table and dug in the potato chip bag. "If Jack ever gets out of the shower he'll get the water pipe going." She opened the box of snack crackers and put one in her mouth. "Say, these are really good."

"I don't know what Emily Post would say about you," Mary said.

Helen laughed. She shook her head. "I guess I better put these in bowls before I stand here and eat them up." 
Jack came out of the bathroom. "Hi, everybody. Hi, Carl. What's so funny?" he said, grinning. "I could hear you laughing."

"We were laughing at Helen," Mary said.

"She's funny," Jack said. "Look at the goodies! Hey, you guys ready for a glass of creme soda? I'll get the pipe going."

"I'll have a glass," Mary said. "What about you, Carl?"

"I'll have some," Carl said.

"Carl's on a little bummer tonight," Mary said.

"Why do you say that?" Carl asked. He looked at her. "That's a good way to put me on one."

"I was just teasing," she said. She came over and sat beside him on the sofa. "I was just teasing, honey."

"Hey, Carl, don't get on a bummer," Jack said. "Let me show you what I got for my birthday. Helen, will you open one of those bottles of creme soda while I get the pipe going? I'm real dry."

Helen carried the bowls of chips and crackers to the coffee table. Then she carried in a bottle of creme soda and four glasses.

"Looks like we're going to have a party," Mary said.

"If I didn't starve myself all day I'd put on ten pounds a week," Helen said.

"I know what you mean," Mary said.

Jack came out of the bedroom with the water pipe. "What do you think of this?" he said to Carl. He put the water pipe on the coffee table between the two bowls.

"That's really something," Carl said. He picked it up and looked at it.

"It's called a hookah," Helen said. "That's what they called it where I bought it. It's just a little one, of course, but it does the job." She laughed.

"Where did you get it?" Mary said.

"What? That little place on Fourth Street. You know."

"I'll have to go in there some day," Mary said. She folded her hands and watched Jack.

"How does it work?" Carl said.

"You put the stuff here, you see, right here," Jack said. "And you light this. Then you inhale through here and the smoke is filtered through the water. It has a good taste to it and really hits you."

"I'd like to get Carl one for Christmas," Mary said. "Or Halloween, or whatever." She looked at Carl and grinned and touched his arm.

"I'd like to have one," Carl said. He stretched his legs and looked at his shoes under the light.

"Here, try this," Jack said, letting out a thin stream of smoke and passing the tube to Carl. "See if this isn't okay."

Carl drew on the tube, held the smoke, and passed the tube to Helen.

"Mary first," Helen said. "I'll go after Mary. You guys have to catch up."

"I won't argue," Mary said. She slipped the tube in her mouth and drew rapidly, twice, and Carl watched the bubbles.

"That's really okay," Mary said. She passed the tube to Helen. 
"It's good, isn't it?" Helen said. "We broke it in last night."

"She was still stoned when she got up with the kids this morning," Jack said and laughed. He watched Helen pull on the tube.

"How are the kids?" Mary asked.

"They're fine," Jack said and put the tube in his mouth.

Carl sipped the creme soda and watched the bubbles. They reminded him of bubbles rising from a diving helmet. He imagined a lagoon and schools of fish. Jack passed the tube.

In a little while Carl stood up and stretched.

"Where are you going, honey?" Mary asked.

"No place," he said. He sat down and shook his head and grinned. "Jesus."

Helen laughed.

"What's funny?" Carl said after a minute.

"God, I don't know," she said. She wiped her eyes and laughed again, and Mary and Jack laughed.

After a time Jack unscrewed the top of the water pipe and blew through one of the tubes. "It gets plugged sometimes."

"What did you mean when you said I was on a bummer?" Carl said to Mary.

"What?" she said.

Carl stared at her and blinked. "You said something about me being on a bummer. What made you say that?"

"I don't remember now, but I can tell when you are," she said. "But please don't bring up anything negative, okay?"

"Okay. All I'm saying is I don't know why you said that. If I wasn't on a bummer before you said it, it's enough when you say it to put me on one."

"If the shoe fits," Mary said. She leaned on the arm of the sofa and laughed until tears came.

"What was that?" Jack said. He looked at Carl and then at Mary. "I missed that one."

"I should have made some dip for these chips," Helen said.

"Wasn't there another bottle of that creme soda?" Jack said.

"We brought two bottles," Carl said.

"Did we drink them both?" Jack asked.

"Did we drink any?" Helen said and laughed. "No, I only opened one. I think I only opened one. I don't remember opening any more."

Carl passed the tube to Mary. She took his hand and guided the tube into her mouth. He watched the smoke flow over her lips a minute later.

"What about some creme soda?" Jack said.

Mary and Helen laughed.

"What about it?" Mary said.

"Well, I thought we were going to have us a glass," Jack said. He looked at Mary and grinned.

Mary and Helen kept laughing.

"What's funny?" Jack said. He looked at Helen and then at Mary. He shook his head. "I don't know about you guys." 
"We might go to Alaska," Carl said.

"Alaska?" Jack said. "What's in Alaska? What makes you say that? What would you do up there?"

"I wish we could go someplace," Helen said.

"What's wrong with here?" Jack said to her. "What would you guys do in Alaska? I'm serious, I'd like to know."

Carl put a potato chip in his mouth and sipped his creme soda. "I don't know. What'd you say?"

After a while Jack said, "What's in Alaska?"

"I don't know," Carl said. "Ask Mary. Mary knows. Mary, what are we going to do up there? Maybe I'll grow those giant cabbages you read about sometimes."

"Or pumpkins," Helen said. "Grow pumpkins. For Halloween."

"You'd clean up," Jack said. "Ship the pumpkins down here for Halloween. I'll be your distributor."

"Jack will be your distributor," Helen said.

"That's right," Jack said. "We'll clean up."

"Get rich," Mary said.

In a while Jack stood up. "I know what would taste good and that's some creme soda."

Mary and Helen laughed.

"Go ahead and laugh," Jack said, grinning. "Who wants some?"

"Some what?" Mary said.

"Some creme soda," he said.

"You stood up like you were going to make a speech," Mary said.

"I hadn't thought of that," he said. He shook his head and laughed. "Well, it beats me." He sat down. "You know, damn, that's good stuff."

"We should have got more," Helen said.

"More what?" Mary said.

"More money," Jack said.

"No money," Carl said.

"Did I see some U-No bars in that sack?" Helen said.

"I bought some," Carl said. "I spotted them at the last minute."

"U-No bars are good," Jack said.

"They're creamy," Mary said. "They dissolve in your mouth."

"We have some M and M's and popsicles if anybody wants any," Jack said.

"Helen told us," Mary said. "I might have a popsicle. Are you going out in the kitchen?"

"Yeah, and I'm going to get the creme soda, too, I just remembered. You guys want a glass?"

"Just bring it all in and we'll decide then," Helen said. "The M and M's too."

"Might be easier to move the kitchen out here," Jack said. "Save steps."

"When we lived in The City," Mary said, "people said you could see who'd turned-on the night before by looking at their kitchen the next morning. We had a tiny kitchen when we lived in The City," she added after a minute. 
"We had a tiny kitchen too," Carl said.

"I'm going out to see what I can find," Jack said.

"I'll come with you," Mary said.

Carl watched them walk to the kitchen. He settled back against the cushion and watched them walk, then leaned forward slowly. He squinted. He saw Jack reach up to a shelf in the cupboard. He saw Mary lean against Jack from behind and put her arms around his waist.

"Are you guys serious?" Helen said.

"Very serious," Carl said.

“About Alaska," Helen said.

He stared at her.

"I thought you said something," she said.

Jack and Mary came back. Jack carried a large bag of $M$ and M's and a bottle of creme soda. Mary sucked on an orange popsicle.

"Anybody want a sandwich?" Helen said. "We have sandwich materials."

"Isn't it funny?" Mary said. "You start with the desserts first and then you move on to the main course."

"It's real funny," Carl said.

“Are you being sarcastic, honey?" Mary asked.

"Who wants creme soda?" Jack said. "A round of creme soda coming up."

Carl held his glass out and Jack poured it full. Carl set the glass on the coffee table but a minute later brushed it with his arm, and the soda poured onto his shoe.

"Goddamn it," Carl said as he watched the liquid seep into the soft leather. "How do you like that? I spilled it on my shoe."

"Helen, do we have a towel? Get Carl a towel," Jack said.

"Those were new shoes," Mary said. "He just got them tonight."

"I noticed them," Helen said and handed Carl a towel. "They look comfortable."

"That's what I told him," Mary said.

Carl took the shoe off and rubbed the leather with the towel. "It's done for," he said. "That creme soda will never come out."

Mary, Jack, and Helen laughed.

"That reminds me, I read something in the paper," Helen said. She pushed on the tip of her nose with a finger and narrowed her eyes. "I can't remember what it was now," she said.

Carl worked the shoe back on. He put both feet under the lamp and looked at the shoes. One shoe was darker than the other.

"What did you read?" Jack said.

"What?" Helen said.

"You said you read something in the paper," Jack said.

Helen laughed. "I was just thinking about Alaska, and I remembered them finding a prehistoric man in a block of ice. Something reminded me."

"That wasn't in Alaska was it?" Jack said. "Well, I don't know, maybe it was."

"Maybe it wasn't, but it reminded me of it." 
"What about Alaska you guys?" Jack said.

"There's nothing in Alaska," Carl said.

"He's on a bummer," Mary said.

"What'll you guys do in Alaska?" Jack said.

"There's nothing to do in Alaska," Carl said. He put his feet under the coffee table. Then he moved them out under the light once more. "Who wants a new pair of shoes? Cheap."

"What's that noise?" Helen said.

They listened. Something scratched the door.

"It sounds like Cindy," Jack said. "I'd better let her in."

"While you're up get me a popsicle," Helen said. She put her head back and laughed. Her mouth was open and her lips glistened.

"I'll have another one too, honey," Mary said. "What did I say? I mean Jack. Excuse me. I thought I was talking to Carl."

"Popsicles all around," Jack said. "You want a popsicle, Carl?"

"What?"

"You want an orange popsicle?"

"An orange one," Carl said.

"Four popsicles coming up," Jack said.

In a while he came back with the popsicles and handed them around. He sat down again and they heard the scratching once more. "I knew I was forgetting something," he said. He got up and opened the front door.

"Good Christ," he said, "if this isn't something. I guess Cindy went out for dinner tonight. Hey, you guys, look at this."

The cat carried a mouse into the living room, stopped to look at them, then carried the mouse into Jack and Helen's bedroom.

"Did you see what I just saw?" Mary said. "Talk about a bummer."

Jack turned the bedroom light on. The cat carried the mouse out of the bedroom and into the bathroom. "She's eating this mouse," he said after a minute. "I don't believe it. She's never eaten a mouse before."

"I don't think I want her eating a mouse in my bathroom," Helen said. "Make her get out there. Some of the children's things are in there."

"She's not going to hurt anything," Jack said.

"What about the mouse?" Mary said.

"What the hell. Cindy's got to learn to hunt sometime. Especially if we're going to move to Alaska," Jack said. "What the hell."

"Alaska?" Helen said. "What's all this about Alaska?"

"Don't ask me," Jack said. He stood near the bathroom door and watched the cat. "Mary and Carl said they're going. Didn't you guys say that? I don't know. But whether they do or not has nothing to do with it. Cindy's got to learn to hunt. I can't just drive her outside."

Mary put her chin in her hands and stared into the bathroom. "She's actually eating that mouse. God."

Helen finished the last of the Frito chips. "I told him I didn't want Cindy eating a mouse in the bathroom. Jack?"

"What?" 
"Make her get out of the bathroom, I said."

"For Christ's sake," he said.

"Look," Mary said. "Ugh."

"What's she doing?" Carl said. "Here, get away," he said as the cat came to him. "Shoo." The cat turned and carried the mouse under the kitchen table. She lay down under the table and began to lick the mouse. She held the mouse in her paws and licked slowly from the head to the base of the tail.

"That cat acts like she's high," Jack said.

"It gives you the shivers," Mary said.

"It's just nature," Jack said. "She's got to live."

"Look at her eyes," Mary said. "Look at the way she looks at us. She's high all right."

Jack came over to the sofa and sat beside Mary. Mary inched toward Carl to give Jack room. She rested her hand on Carl's knee. They watched the cat eat the mouse.

"Don't you ever feed that cat?" Mary said to Helen.

Helen laughed.

"You guys ready for another smoke?" Jack said.

"We should go," Carl said.

"What's your hurry?" Jack said.

"Stay a little longer," Helen said. "You don't have to go yet."

Carl stared at Mary who was staring at Jack. Jack stared at something on the rug near his feet. Helen picked through the $M$ and M's in her hand. "I like the green ones best," she said.

"I have to work in the morning," Carl said.

"What a bummer that is," Mary said. "You want to hear a bummer, folks, there's a bummer."

"Are you coming?" Carl said to her.

"Anybody want a glass of milk?" Jack said. "We've got some nice cold milk out there."

"I'm too full of creme soda," Mary said.

"There's no more creme soda," Jack said.

Helen laughed. She closed her eyes and then opened them and laughed again.

"We have to go home," Carl said. In a while he stood and said, "Did we have coats? I don't think we had coats, did we?"

"What? I don't think we had coats," Mary said. She stayed seated.

"We'd better go," Carl said.

"They have to go," Helen said.

Carl put his hands under Mary's shoulders and pulled her up.

"Goodbye, you guys," Mary said. She embraced Carl. "Thanks for everything. I'm so full I can hardly move."

Helen laughed.

"Helen's always finding something to laugh at," Jack said and grinned. "What are you laughing at, Helen?"

"I don't know. Something Mary said." 


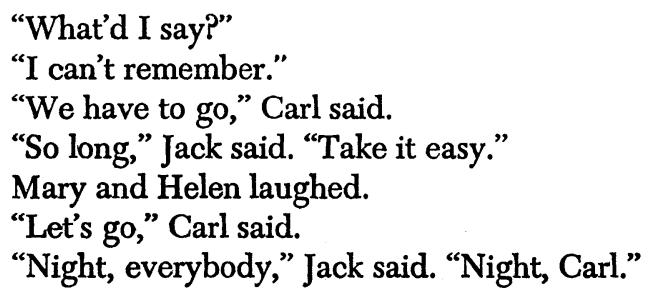

Outside Mary held Carl's arm and walked with her head down. They moved slowly on the sidewalk. He listened to the scuffing sounds her shoes made. He heard the sharp and distinct sound of a dog barking, and above that a murmuring of distant traffic that sounded like wind in tall trees.

She raised her head. "When we get home, Carl, I want to be fucked, talked to, diverted. Divert me, Carl. I need to be diverted tonight." She tightened her hold on his arm.

He could feel the dampness in one shoe. He unlocked the door and flipped the light.

"Come to bed," she said.

"I'm coming," he said.

He went to the kitchen and drank two glasses of water. He turned off the living room light and felt his way along the wall into the bedroom.

"Carl!" she yelled. "Carl!"

"Jesus Christ, it's me! I'm trying to get the light on." He found the lamp and she sat up in bed. Her eyes were bright. She stared at him and breathed with her mouth open. He pulled the stem on the alarm and began taking his clothes off. His knees trembled.

"Is there anything else to smoke?" she asked.

"We don't have anything," he said.

"Fix me a drink then. We have something to drink, don't we? Don't tell me we don't have anything."

"Just some beer."

They stared at each other.

"I'll have a beer," she said.

"You really want a beer?"

She nodded slowly and chewed her lip.

He came back with the beer. She was sitting with his pillow on her lap. He gave her the can of beer and then crawled into bed and pulled the covers up.

"I forgot to take my pill," she said.

"What?"

"I forgot my pill."

He got out of bed and brought her the pill. She opened her eyes and he dropped the pill on her outstretched tongue. She swallowed some beer with the pill and he got back in bed.

"Take this, I can't keep my eyes open," she said.

He set the can on the floor and then stayed on his side and stared into the dark hallway. She put her arm over his ribs and her fingers stroked his chest. 
"What's in Alaska?" she said. He turned on his stomach and eased away to the far side of the bed. In a moment she was snoring.

Just as he started to turn the lamp off, he thought he saw something in the hall. He kept staring and saw it again, a small pair of eyes. His heart turned. He blinked and kept staring. He leaned over to look for something to throw. He picked up one of his shoes. He sat up straight and held the shoe with both hands. He heard her snoring and he set his teeth. He waited. He waited for it to move once more, or make the slightest noise. 